\title{
Article \\ Quetiapine-Induced Place Preference in Mice: Possible Dopaminergic Pathway
}

\author{
Yusuf S. Althobaiti $1,2,3, * \mathbb{D}$ \\ 1 Department of Pharmacology and Toxicology, College of Pharmacy, Taif University, P.O. Box 11099, \\ Taif 21944, Saudi Arabia \\ 2 College of Pharmacy, Addiction and Neuroscience Research Unit, Taif University, Taif 21944, Saudi Arabia \\ 3 Ministry of Interior, General Directorate of Narcotics Control, General Administration for Precursors and Laboratories, \\ Riyadh 11543, Saudi Arabia
}

check for

updates

Citation: Althobaiti, Y.S Quetiapine-Induced Place Preference in Mice: Possible Dopaminergic Pathway. Pharmaceuticals 2021, 14, 156. https://doi.org/10.3390/ ph14020156

Academic Editor: Mary Meegan

Received: 19 December 2020

Accepted: 10 February 2021

Published: 14 February 2021

Publisher's Note: MDPI stays neutral with regard to jurisdictional claims in published maps and institutional affiliations.

Copyright: (C) 2021 by the author. Licensee MDPI, Basel, Switzerland. This article is an open access article distributed under the terms and conditions of the Creative Commons Attribution (CC BY) license (https:// creativecommons.org/licenses/by/ $4.0 /)$.

\begin{abstract}
Quetiapine, an atypical antipsychotic, is effective in the management of schizophrenia, depression, and anxiety. Although quetiapine overdosage and misuse have been reported, its abuse potential has not been investigated in animals. In this study, the abuse potential of quetiapine was assessed based on the conditioned place preference (CPP) paradigm of drug addiction in a mouse model. First, mice received intraperitoneal injections of quetiapine $(40,80$, or $120 \mathrm{mg} / \mathrm{kg})$ every other day during the conditioning phase. In the second experiment, mice were pretreated with $0.03 \mathrm{mg} / \mathrm{kg}$ SKF-35866, a D1 receptor antagonist, before receiving saline or quetiapine $(120 \mathrm{mg} / \mathrm{kg})$ during the conditioning phase. No significant changes in time spent in the quetiapine-paired chamber were observed compared with time spent in the saline-paired chamber in mice treated with $40 \mathrm{or} 80 \mathrm{mg} / \mathrm{kg}$. In contrast, the preference to the quetiapine-paired chamber was significantly increased in mice treated with $120 \mathrm{mg} / \mathrm{kg}$ quetiapine, and this effect was blocked by SKF-35866 pretreatment. These results demonstrated, for the first time, the abuse potential of quetiapine in an animal model of drug addiction. Interestingly, this CPP-inducing effect was likely mediated by activating D1 receptors.
\end{abstract}

Keywords: quetiapine; reward; conditioned place preference; abuse

\section{Introduction}

Quetiapine, an atypical antipsychotic and derivative of dibenzothiazepine, is effective in the management of schizophrenia, bipolar disorder, and major depressive disorder, in combination with serotonin-norepinephrine reuptake inhibitors or selective serotonin reuptake inhibitors [1,2]. In addition, quetiapine has shown efficacy in the treatment of depression and anxiety as a monotherapy [3,4]. Notably, the effects of this drug are mediated by blocking various receptors, including serotonin (5-HT1A, 5-HT2A), dopamine (D2), adrenergic $(\alpha 1, \alpha 2)$, and histamine $(\mathrm{H} 1)$ receptors [5].

Some cases of quetiapine overdosage and misuse have been reported [6-10]. In a retrospective review of 3497 cases of atypical antipsychotic drugs (2118 of which were quetiapine and 1379 of which were other medications, such as risperidone, olanzapine, aripiprazole, clozapine, and ziprazidone), the intentional abuse of quetiapine was compared with that of other atypical antipsychotic drugs, and quetiapine was reported the most commonly abused atypical antipsychotic [11]. In another systematic, retrospective review of data gathered from a drug abuse warning network on quetiapine-related visits to the emergency department, a high number of visits related to the misuse and abuse of quetiapine was reported, suggesting high potential for abuse [12]. These cases of quetiapine abuse suggest that quetiapine could be a new abused agent. However, this drug is widely available and is not designated as a controlled substance, enabling abusers to obtain the drug easily without being arrested or punished.

In the central nervous system, several neurotransmitters can be affected by psychoactive drug intake [13]. For example, dopamine has strong effects on drug-seeking and 
reinforcing behaviors [14]. In fact, increased concentrations of dopamine in the brain regions involved in drug-seeking behaviors have been reported following exposure to several abuse-related drugs [15], and drug-seeking behaviors in response to several drugs can be prevented by blocking dopaminergic receptors [16-18]. In particular, dopaminergic D1 receptors have been reported to play major roles in the reward system in the brain [19-23]. However, motor functions have been consistently reported to be mediated through D2 receptors [24,25].

Preclinical studies of quetiapine abuse potential have yielded inconsistent results. In a conditioned place preference (CPP) animal study, 10, 20, or $40 \mathrm{mg} / \mathrm{kg}$ quetiapine did not show any effects on CPP when administered alone [26]. In another study that tested quetiapine abuse potential in rodents using CPP and self-administration animal models, the tested doses $(0.1,0.5$, and $1 \mathrm{mg} / \mathrm{kg})$ did not produce any significant increase in place preference scores. These CPP findings suggested that there was no abuse potential for these low doses. In self-administration experiments, animals engaged in frequent quetiapine self-administration, suggesting that this drug may have reinforcing effects [27]. However, the abuse potential of quetiapine remains unclear.

Therefore, in this study, the abuse potential of quetiapine was evaluated in a CPP model. Additionally, the possible mechanisms through which the drug may activate the reward system in the brain to promote abuse were also assessed.

\section{Results}

\subsection{Experiment 1}

In the control group treated with saline, two-way RM ANOVA revealed a nonsignificant main effect of phase $(\mathrm{F}(1,7)=1.000, p=0.3506)$ or chamber $(\mathrm{F}(1,7)=0.1482, p=0.9241)$ and a nonsignificant phase $\times$ chamber interaction $(\mathrm{F}(1,7)=0.2759, p=0.8704$; Figure $1 \mathrm{~A})$. In the Quet-40 group treated with quetiapine $(40 \mathrm{mg} / \mathrm{kg})$, two-way RM ANOVA revealed a nonsignificant main effect of phase $(\mathrm{F}(1,9)=1.040, p=0.3345)$ or chamber $(\mathrm{F}(1,9)=0.7591$, $p=0.4062)$ and a nonsignificant phase $\times$ chamber interaction $(\mathrm{F}(1,9)=1.811, p=0.2114$; Figure 1B).

A

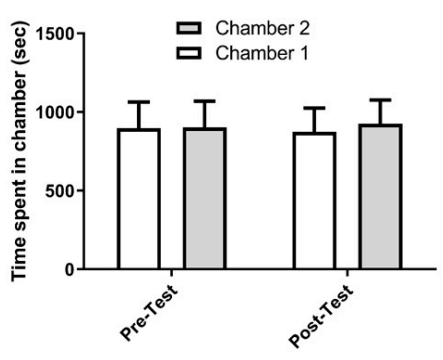

Saline $(10 \mathrm{ml} / \mathrm{kg})$

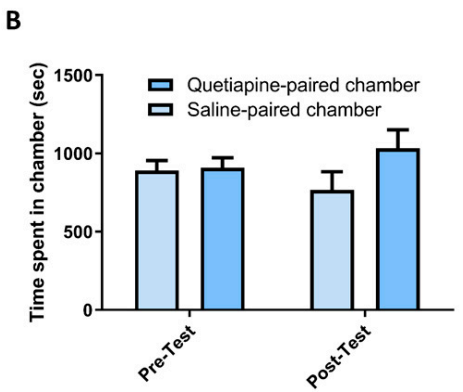

Quetiapine (40 mg/kg)

Figure 1. (A) Time spent in chamber 1 compared with chamber 2 during the pretest and post-test in the control group. (B) Time spent in the quetiapine-paired chamber compared with the saline-paired chamber during the pretest and post-test in the Quet-40 group (treated with quetiapine $40 \mathrm{mg} / \mathrm{kg}$ ). Values are shown as means \pm standard errors of the means.

In the Quet-80 group treated with quetiapine $(80 \mathrm{mg} / \mathrm{kg})$, two-way RM ANOVA revealed a nonsignificant main effect of phase $(\mathrm{F}(1,7)=1.000, p=0.3506)$ or chamber $(\mathrm{F}(1,7)=0.9837$, $p=0.3543)$ and a nonsignificant phase $\times$ chamber interaction $(\mathrm{F}(1,7)=1.517, p=0.2578$; Figure 2A). In the Quet-120 group treated with quetiapine $(120 \mathrm{mg} / \mathrm{kg})$, two-way RM ANOVA revealed a nonsignificant main effect of phase $(\mathrm{F}(1,8)=1.000, p=0.3466)$, but a significant effect of chamber $(\mathrm{F}(1,8)=0.6 .469, p=0.0345)$ and a significant phase $\times$ chamber interaction ( $F(1,8)=9.112, p=0.0166$; Figure 2B). Newman-Keuls multiple comparisons tests showed that there was a significant increase in the time spent in the quetiapine-paired chamber 
compared with the saline-paired chamber during the post-test $(p<0.05)$. No significant changes were detected in the time spent in the quetiapine-paired chamber compared with the saline-paired chamber during the pretest. There were also no significant changes when comparing the time spent in any given chamber between the post-test and pretest.

A

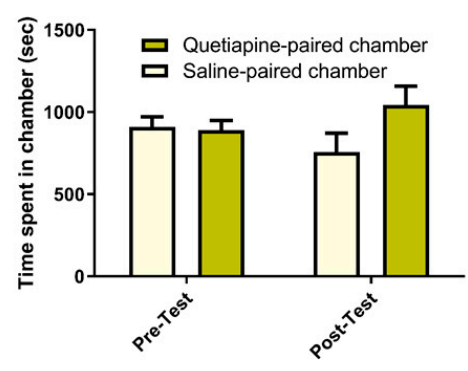

Quetiapine (80 mg/kg)
B

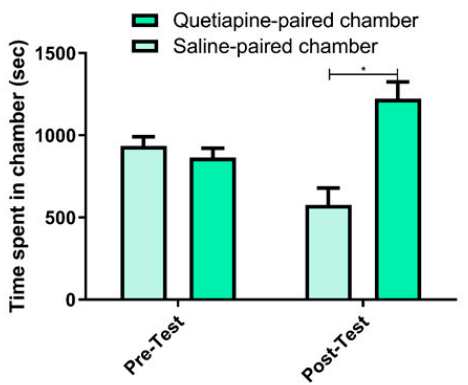

Quetiapine (120 mg/kg)

Figure 2. (A) Time spent in the quetiapine-paired chamber compared with the saline-paired chamber during pretest and post-test in the Quet-80 group (treated with quetiapine; $80 \mathrm{mg} / \mathrm{kg}$ ). (B) Time spent in the quetiapine-paired chamber compared with the saline-paired chamber during pretest and post-test in the Quet-120 group (treated with quetiapine; $120 \mathrm{mg} / \mathrm{kg}$ ). Values are shown as means \pm standard errors of the means. ${ }^{*} p<0.05$ compared with the saline-paired chamber.

\subsection{Experiment 2}

In the SKF-V group treated with SKF $(0.03 \mathrm{mg} / \mathrm{kg})$ followed by saline, two-way RM ANOVA revealed a nonsignificant main effect of phase $(\mathrm{F}(1,6)=1.000, p=0.3559)$ or chamber $(\mathrm{F}(1,6)=0.02992, p=0.8684)$ and a nonsignificant phase $\times$ chamber interaction $(\mathrm{F}(1,6)=0.007901, p=0.9321$; Figure 3A). In the SKF-Quet group treated with SKF $(0.03 \mathrm{mg} / \mathrm{kg})$ followed by quetiapine $(120 \mathrm{mg} / \mathrm{kg})$, two-way RM ANOVA revealed a nonsignificant main effect of phase $(\mathrm{F}(1,7)=2.320, p=0.1715)$ or chamber $(\mathrm{F}(1,7)=0.03032$, $p=0.8667)$ and a nonsignificant phase $\times$ chamber interaction $(\mathrm{F}(1,7)=0.004477, p=0.9485$; Figure 3B).

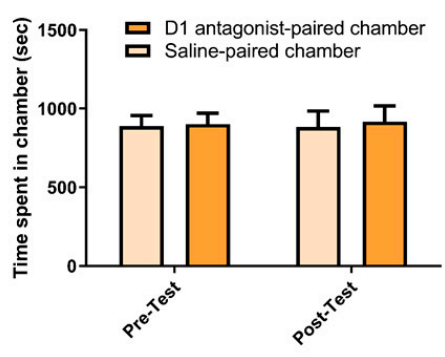

SKF-V

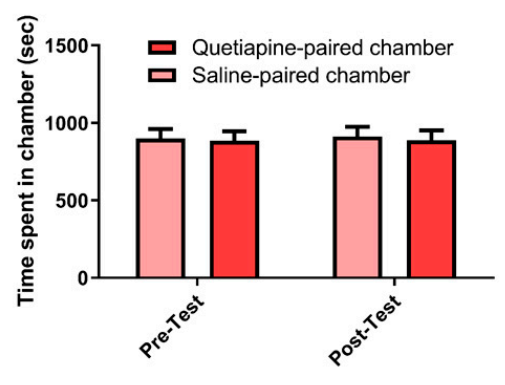

SKF-Quetiapine $(120 \mathrm{mg} / \mathrm{kg})$

Figure 3. (A) Time spent in the D1 antagonist-paired chamber compared with the saline-paired chamber during pretest and post-test in the SKF-V group (treated with SKF followed by vehicle). (B) Time spent in the quetiapine-paired chamber compared with the saline-paired chamber during pretest and post-test in the SKF-Quet group (treated with SKF followed by quetiapine). Values are shown as means \pm standard errors of the means.

\section{Discussion}

In this study, the ability of quetiapine to induce CPP in mice was discovered. The important roles of D1 receptors in this effect were also elucidated. The findings suggested 
that quetiapine activated the reward system in the brain, which could explain the increased place preference found in this study with the highest tested dose of $120 \mathrm{mg} / \mathrm{kg}$. Notably, one preclinical study contradicted the current findings and concluded that quetiapine did not show any addictive potential because it did not affect place preference in the tested rats [26]. However, this previous study tested lower doses of quetiapine $(10,20$, and $40 \mathrm{mg} / \mathrm{kg}$ ) compared with the doses used in the current study $(40,80$, and $120 \mathrm{mg} / \mathrm{kg})$. Consistent with this previous study, CPP was not affected by $40 \mathrm{mg} / \mathrm{kg}$ quetiapine in the current study. Interestingly, when the dose was increased to $80 \mathrm{mg} / \mathrm{kg}$, preference tended to increase, although the change was not significant. Furthermore, a significant preference for the quetiapine-paired chamber was found when the dose was increased to $120 \mathrm{mg} / \mathrm{kg}$. This suggested that the drug had dose-dependent effects on the reward system in the brain. Importantly, the findings in this study were supported by several case reports of quetiapine abuse/misuse at higher doses. For example, a 34-year-old female subject with a history of substance use disorder crushed her pills, dissolved them in water, and injected herself with $600 \mathrm{mg}$ quetiapine [28]. Similarly, several reports have described cases of patients with a history of polysubstance abuse who snorted [29] or received [30] high doses of quetiapine and experienced rush sensations and withdrawal symptoms. In addition, a retrospective study was conducted on cases of abuse/misuse of quetiapine from poison centers in the USA from 2005 to 2011. In total, 1948 cases met the criteria for misuse, defined as improper use of drugs, such as increasing the dose to enhance its effects, whereas 1168 cases met the criteria for abuse, i.e., the intentional use of the drug to get high, including recreational use; higher numbers were observed among adolescents [31].

Quetiapine has multiple street names, including "quell," "Susie-Q," "baby heroin", and "Q-ball" [32-35]. Thus, the drug is a known, abuse-related drug among addicts, further supporting the current findings on CPP induction in a mouse model of drug addiction. Some previous studies have been conducted in animals to elucidate the effects of quetiapine and determine whether the drug induced addiction. In a study of the potential dependence of quetiapine in mice, researchers used the same CPP method, but lower doses $(5,7$, and $10 \mathrm{mg} / \mathrm{kg}$ ) of quetiapine and found a dose-dependent effect; however, the result was not statistically significant. In self-administration experiments, animals engaged in frequent self-administration of quetiapine, suggesting that this drug may have reinforcing effects [27].

Because the drug can function by blocking various receptors, including serotonin (5-HT1A, 5-HT2A) receptors and dopamine (D2) receptors [36,37], quetiapine can increase the release of dopamine [38]. Accordingly, quetiapine abuse may be driven by D1 receptor activation, which is well known to activate the reward system in the brain and lead to addiction [39]. Although the exact mechanism through which quetiapine can induce reward is not known, several well-known, abuse-related drugs have been shown to induce drugseeking behavior through the modulation of dopamine [40]; the same mechanism may be involved in quetiapine abuse. Rewarding and reinforcing behaviors have been shown to be induced by dopamine release in the nucleus accumbens and D1 receptor activation [41,42]. Interestingly, SKF-83566 has been shown to interfere with dopamine release induced by cocaine and block hyperlocomotion caused by amphetamine exposure $[43,44]$. In this study, the effects of blocking D1 receptors were tested by pretreating mice with a D1 antagonist, SKF-35866, before the administration of the dose of quetiapine that induced CPP $(120 \mathrm{mg} / \mathrm{kg})$. This pretreatment with SKF-35866 completely blocked CPP to quetiapine, suggesting that D1 receptors play important roles in activating the reward system of the brain in response to quetiapine.

One limitation of this study is that dopamine release and its concentration in the key brain regions of the reward pathway were not assessed following exposure to quetiapine. Further studies are needed to explore the neurobiological changes induced by quetiapine. 


\section{Materials and Methods}

\subsection{Animals}

Male BALB/c mice (King Fahd Medical Research Center, Jeddah, Saudi Arabia), weighing 20-30 $\mathrm{g}$ at the beginning of the study, were housed in standard plastic tubes with controlled humidity $(30 \%)$ and temperature $\left(21^{\circ} \mathrm{C}\right)$ on a 12:12 light-dark photoperiod, and were allowed to habituate for $7 \mathrm{~d}$ before experiments. Mice were provided food and water ad libitum throughout the experiment. All experiments were performed during the light cycle. In accordance with the Institutional Animal Care and Use Committee of the National Institutes of Health guidelines, the experimental procedures of the animal study were approved by the Research Ethics Committee at Taif University.

\subsection{Drugs}

Quetiapine was a donation from Riyadh Pharma (Riyadh, Saudi Arabi). SKF-83566 was obtained from Tocris Bioscience (Ellisville, MO, USA). Saline solution vehicle $(0.9 \%$ $\mathrm{NaCl}$ ) was used to reconstitute all drugs used in this study.

\subsection{Experimental Design}

Experiment 1: Animals were randomly separated into four groups: control group $(n=8)$, administered vehicle $(10 \mathrm{~mL} / \mathrm{kg}$, intraperitoneal (i.p.) injection) for $8 \mathrm{~d}$; Quet-40 group $(n=8)$, administered quetiapine $(40 \mathrm{mg} / \mathrm{kg}$, i.p. injection four times) and vehicle $(10 \mathrm{~mL} / \mathrm{kg}$, i.p. injection four times) for $8 \mathrm{~d}$ during the conditioning phase; Quet-80 group $(n=8)$, administered quetiapine $(80 \mathrm{mg} / \mathrm{kg}$, i.p. injection four times) and vehicle $(10 \mathrm{~mL} / \mathrm{kg}$, i.p. injection four times) for $8 \mathrm{~d}$ during the conditioning phase; and Quet-120 group $(n=8)$, administered quetiapine $(120 \mathrm{mg} / \mathrm{kg}$, i.p. injection four times) and vehicle $(10 \mathrm{~mL} / \mathrm{kg}$, i.p. injection four times) for $8 \mathrm{~d}$ during the conditioning phase.

Experiment 2: Animals were randomly assigned to two groups: SKF-V group $(n=7)$, administered SKF-83566 (0.03 mg/kg, i.p. injection) $30 \mathrm{~min}$ before vehicle $(10 \mathrm{~mL} / \mathrm{kg}$, i.p. injection eight times) for $8 \mathrm{~d}$ during the conditioning phase; and SKF-Quet group $(n=8)$, administered SKF-83566 (0.03 mg/kg, i.p. injection) $30 \mathrm{~min}$ before quetiapine $(120 \mathrm{mg} / \mathrm{kg}$, i.p. injection four times) for $8 \mathrm{~d}$ during the conditioning phase.

\subsection{CPP Paradigm}

The CPP apparatus was made of acrylic and consisted of two conditioning chambers, which were identical in size and distinguished by both tactile and visual cues, as described previously [45]. In the habituation phase (days 1-3), each mouse was placed in the start box with the door closed for $3 \mathrm{~min}$. Then, the door was opened, and the mouse had free access to both chambers for $30 \mathrm{~min}$. On day 3, mouse movement in the two chambers was recorded (pretest) and the time spent in each chamber was calculated using the ANY-maze software (Stoelting, USA). An unbiased CPP design was followed and, to eliminate possible bias to any chamber, mice spending $>67 \%$ of the total time in any one chamber were excluded from the study [45-47]. Moreover, half of the animals were randomly assigned to receive quetiapine in chamber 1 and the remaining half received it in chamber 2.

In the conditioning phase (days 4-11), each mouse received the selected dose of quetiapine according to the assigned group and was confined, immediately after the injection, into the designated chamber for $30 \mathrm{~min}$. The next day, each animal received the vehicle dose $(10 \mathrm{~mL} / \mathrm{kg})$ and was confined into the opposite chamber for $30 \mathrm{~min}$. On day 12 , mouse movement in the two chambers was recorded (post-test) and the time spent in each chamber was calculated using the ANY-maze system. In experiment 2, the same process was performed during the conditioning phase, except that animals received a 30-min pretreatment with SKF-83566 before the administration of saline or quetiapine (Figure 4). 


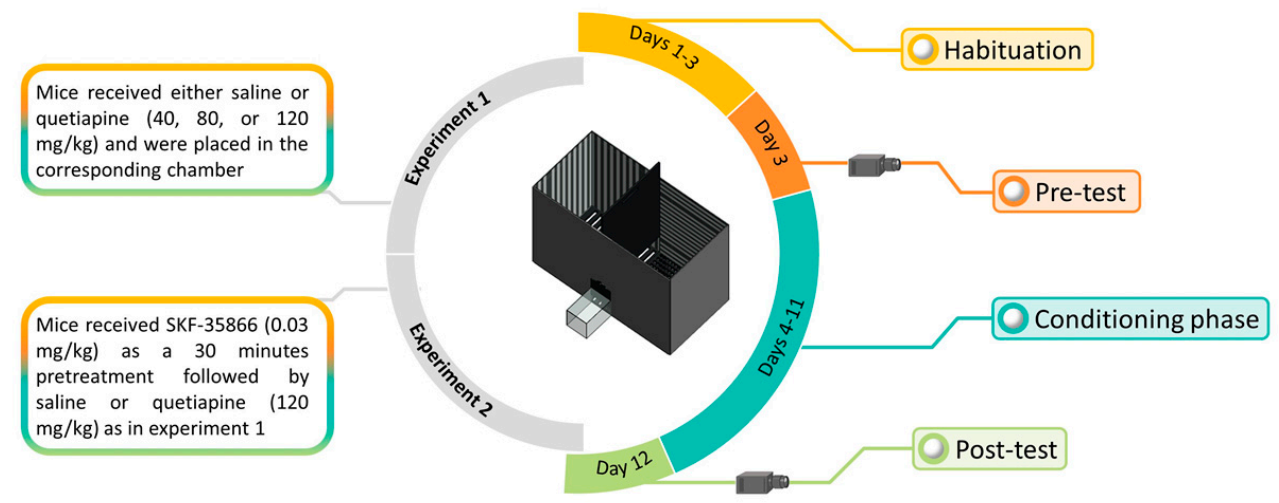

Figure 4. Experimental schedule of the conditioned place preference (CPP) experiments.

\subsection{Statistical analysis}

Two-way repeated measures (RM) analysis of variance (ANOVA; phase $\times$ chamber) was used to analyze the time spent in the conditioning chambers. Newman-Keuls comparisons were applied when significant main effects or interactions were identified. All data were statistically analyzed using GraphPad Prism, with a significance level of 0.05.

\section{Conclusions}

The findings of this study showed, for the first time, that quetiapine could cause drugrelated effects in CPP experiments in mice. The results also showed that this CPP-inducing effect was likely mediated by activating D1 receptors, as is addiction. Based on this important evidence, the use of this drug should be restricted. Healthcare providers should be aware of the important potentially-addictive effects of this drug and plan prescriptions accordingly, especially in patients with a history of substance abuse disorder. The concerned authorities may consider these findings when establishing guidelines for the restricted use of quetiapine to decrease its abuse potential.

Funding: This research received no external funding.

Institutional Review Board Statement: All experiments in this study were approved by the Scientific Research Ethics Committee at Taif University (42-0112).

Informed Consent Statement: Not applicable.

Data Availability Statement: Available upon reasonable request.

Acknowledgments: The author was supported by Taif University Researchers Supporting Project number (TURSP-2020/78), Taif University, Taif, Saudi Arabia. The author would like to thank Hussam Almalki, Abdulrahman Alghamdi, and Ahmad Basfer for their help with the experiments. The author thanks Roaa Alsulaimani and Zainab Alahmary for their help in figures.

Conflicts of Interest: The author declares no conflict of interest.

\section{References}

1. Maglione, M.; Maher, A.R.; Hu, J.; Wang, Z.; Shanman, R.; Shekelle, P.G.; Roth, B.; Hilton, L.; Suttorp, M.J.; Ewing, B.A.; et al. Off-Label Use of Atypical Antipsychotics: An Update; Agency for Healthcare Research and Quality (US): Rockville, MD, USA, 2011.

2. Oruch, R.; Pryme, I.; Fasmer, O.B.; Lund, A. Quetiapine: An Objective Evaluation of Pharmacology. Clin. Uses Intox. 2020, 8, 1-26.

3. Maneeton, N.; Maneeton, B.; Woottiluk, P.; Likhitsathian, S.; Suttajit, S.; Boonyanaruthee, V.; Srisurapanont, M. Quetiapine monotherapy in acute treatment of generalized anxiety disorder: A systematic review and meta-analysis of randomized controlled trials. Drug Des. Dev. Ther. 2016, 10, 259-276. [CrossRef]

4. Simon, J.; Geddes, J.R.; Gardiner, A.; Rendell, J.; Goodwin, G.M.; Mayer, S. Comparative economic evaluation of quetiapine plus lamotrigine combination vs quetiapine monotherapy (and folic acid vs placebo) in patients with bipolar depression (CEQUEL). Bipolar Disord. 2018, 20, 733-745. [CrossRef] [PubMed]

5. Maan, S.J.; Saadabadi, A. Quetiapine, in StatPearls [Internet]; StatPearls Publishing: Treasure Island, FL, USA, 2019.

6. Yam, M.F.-C.; Kiew, C.-F.; Chong, C.-P. Hyperglycemia and late onset seizures associated with quetiapine overdose. Tzu Chi Med. J. 2013, 25, 119-121. [CrossRef] 
7. Nudelman, E.; Vinuela, L.M.; Cohen, C.I. Safety in overdose of quetiapine: A case report. J. Clin. Psychiatry 1998, $59,433$. [CrossRef]

8. Harmon, T.J.; Benitez, J.G.; Krenzelok, E.P.; Cortes-Belen, E. Loss of Consciousness from Acute Quetiapine Overdosage. J. Toxicol. Clin. Toxicol. 1998, 36, 599-602. [CrossRef] [PubMed]

9. Rhyee, S.H.; Pedapati, E.V.; Thompson, J. Prolonged Delirium After Quetiapine Overdose. Pediatr. Emerg. Care 2010, 26, 754-756. [CrossRef] [PubMed]

10. Pierre, J.M.; Shnayder, I.; Wirshing, D.A.; Wirshing, W.C. Intranasal Quetiapine Abuse. Am. J. Psychiatry 2004, 161, 1718. [CrossRef]

11. Klein, L.; Bangh, S.; Cole, J.B. Intentional Recreational Abuse of Quetiapine Compared to Other Second-generation Antipsychotics. West. J. Emerg. Med. 2017, 18, 243-250. [CrossRef]

12. Mattson, M.E.; Albright, V.A.; Yoon, J.; Council, C.L. Emergency Department Visits Involving Misuse and Abuse of the Antipsychotic Quetiapine: Results from the Drug Abuse Warning Network (DAWN). Subst. Abus. Res. Treat. 2015, 9, 39-46. [CrossRef]

13. Bastiaens, L.; Galus, J.; Mazur, C. Abuse of Gabapentin is Associated with Opioid Addiction. Psychiatr. Q. 2016, 87, 763-767. [CrossRef]

14. Solinas, M.; Belujon, P.; Fernagut, P.O.; Jaber, M.; Thiriet, N. Dopamine and addiction: What have we learned from 40 years of research. J. Neural Transm. 2019, 126, 481-516. [CrossRef]

15. Quintero, G.C. Review about gabapentin misuse, interactions, contraindications and side effects. J. Exp. Pharmacol. 2017, 9, 13-21. [CrossRef]

16. Hamamura, T.; Akiyama, K.; Akimoto, K.; Kashihara, K.; Okumura, K.; Ujike, H.; Otsuki, S. Co-administration of either a selective D1 or D2 dopamine antagonist with methamphetamine prevents meth-amphetamine-induced behavioral sensitization and neurochemical change, studied by in vivo intracerebral dialysis. Brain Res. 1991, 546, 40-46. [CrossRef]

17. Woolverton, W.L. Effects of a D1 and a D2 dopamine antagonist on the self-administration of cocaine and piribedil by Rhesus monkeys. Pharmacol. Biochem. Behav. 1986, 24, 531-535. [CrossRef]

18. Yue, K.; Ma, B.; Ru, Q.; Chen, L.; Gan, Y.; Wang, D.; Jin, G.; Li, C. The dopamine receptor antagonist levo-tetrahydropalmatine attenuates heroin self-administration and heroin-induced reinstatement in rats. Pharmacol. Biochem. Behav. 2012, 102, 1-5. [CrossRef] [PubMed]

19. Ranaldi, R.; Beninger, R.J. Bromocriptine enhancement of responding for conditioned reward depends on intact D1 receptor function. Psychopharmacology 1995, 118, 437-443. [CrossRef] [PubMed]

20. Sutton, M.A.; Beninger, R.J. Psychopharmacology of conditioned reward: Evidence for a rewarding signal at D1-like dopamine receptors. Psychopharmacology 1999, 144, 95-110. [CrossRef] [PubMed]

21. Fibiger, H.C. Mesolimbic dopamine: An analysis of its role in motivated behavior. In Seminars in Neuroscience; Elsevier: Amsterdam, The Netherlands, 1993.

22. Grenier, P.; Mailhiot, M.C.; Cahill, C.M.; Olmstead, M.C. Blockade of dopamine D1 receptors in male rats disrupts morphine reward in pain naïve but not in chronic pain states. J. Neurosci. Res. 2019. [CrossRef] [PubMed]

23. Carati, C.; Schenk, S. Role of dopamine D1- and D2-like receptor mechanisms in drug-seeking following methamphetamine self-administration in rats. Pharmacol. Biochem. Behav. 2011, 98, 449-454. [CrossRef]

24. Fowler, S.C.; Liou, J.-R. Microcatalepsy and disruption of forelimb usage during operant behavior: Differences between dopamine D1 (SCH-23390) and D2 (raclopride) antagonists. Psychopharmacology 1994, 115, 24-30. [CrossRef]

25. Beninger, R.J.; Miller, R. Dopamine D1-like receptors and reward-related incentive learning. Neurosci. Biobehav. Rev. 1998, 22, 335-345. [CrossRef]

26. McLelland, A.E.; Martin-Iverson, M.T.; Beninger, R.J. The effect of quetiapine (Seroquel ${ }^{\mathrm{TM}}$ ) on conditioned place preference and elevated plus maze tests in rats when administered alone and in combination with (+)-amphetamine. Psychopharmacology 2014, 231, 4349-4359. [CrossRef] [PubMed]

27. Cha, H.J.; Lee, H.-A.; Ahn, J.-I.; Jeon, S.-H.; Kim, E.J.; Jeong, H.-S. Dependence Potential of Quetiapine: Behavioral Pharmacology in Rodents. Biomol. Ther. 2013, 21, 307-312. [CrossRef]

28. Hussain, M.; Waheed, W.; Hussain, S. Intravenous Quetiapine Abuse. Am. J. Psychiatry 2005, 162, 1755. [CrossRef] [PubMed]

29. Morin, A.K. Possible intranasal quetiapine misuse. Am. J. Heal. Pharm. 2007, 64, 723-725. [CrossRef]

30. Yargic, I.; Caferov, C. Quetiapine Dependence and Withdrawal: A Case Report. Subst. Abus. 2011, 32, 168-169. [CrossRef]

31. Klein-Schwartz, W.; Schwartz, E.K.; Anderson, B.D. Evaluation of Quetiapine Abuse and Misuse Reported to Poison Centers. J. Addict. Med. 2014, 8, 195-198. [CrossRef]

32. Pinta, E.; Taylor, R. Quetiapine addiction?(letter). Am. J. Psychiatry 2007, 164, 174-175, DAVID MURPHY, MD KIMBERLY BAILEY, RN MICHAEL STONE WILLIAM C. WIRSHING, MD Culver City, Calif. [CrossRef] [PubMed]

33. Keltner, N.L.; Vance, D.E. Biological Perspectives Incarcerated Care and Quetiapine Abuse. Perspect. Psychiatr. Care 2008, 44, 202-206. [CrossRef]

34. Waters, M.B.; Joshi, K.G. Intravenous quetiapine-cocaine use (“Q-ball”). Am. J. Psychiatry 2007, 164, 173-174. [CrossRef]

35. Gugger, J.J.; Cassagnol, M. Low-Dose Quetiapine Is Not a Benign Sedative-Hypnotic Agent. Am. J. Addict. 2008, 17, 454-455. [CrossRef] 
36. Ray, L.A.; Chin, P.F.; Heydari, A.; Miotto, K. A human laboratory study of the effects of quetiapine on subjective intoxication and alcohol craving. Psychopharmacology 2011, 217, 341-351. [CrossRef]

37. Seeman, P. Atypical Antipsychotics: Mechanism of Action. Focus 2004, 47, 27-58. [CrossRef]

38. Ichikawa, J.; Ishii, H.; Bonaccorso, S.; Fowler, W.L.; O'Laughlin, I.A.; Meltzer, H.Y. 5-HT2A and D2 receptor blockade increases cortical DA release via 5-HT1A receptor activation: A possible mech-anism of atypical antipsychotic-induced cortical dopamine release. J. Neurochem. 2001, 76, 1521-1531. [CrossRef] [PubMed]

39. Hasbi, A.; Perreault, M.L.; Shen, M.Y.F.; Fan, T.; Nguyen, T.; Alijaniaram, M.; Banasikowski, T.J.; Grace, A.A.; O’Dowd, B.F.; Fletcher, P.J.; et al. Activation of Dopamine D1-D2 Receptor Complex Attenuates Cocaine Reward and Reinstatement of Cocaine-Seeking through Inhibition of DARPP-32, ERK, and $\triangle$ FosB. Front. Pharmacol. 2018, 8, 924. [CrossRef]

40. Justinova, Z.; Panlilio, L.V.; Goldberg, S.R. Drug addiction. In Behavioral Neurobiology of the Endocannabinoid System; Springer: Berlin/Heidelberg, Germany, 2009; pp. 309-346.

41. Baik, J.-H. Dopamine signaling in reward-related behaviors. Front. Neural Circuits 2013, 7, 152. [CrossRef] [PubMed]

42. Ranaldi, R.; Wise, R.A. Blockade of D1 Dopamine Receptors in the Ventral Tegmental Area Decreases Cocaine Reward: Possible Role for Dendritically Released Dopamine. J. Neurosci. 2001, 21, 5841-5846. [CrossRef]

43. Stouffer, M.A.; Ali, S.; Reith, M.E.A.; Patel, J.C.; Sarti, F.; Carr, K.D.; Rice, M.E. SKF-83566, a D1-dopamine receptor antagonist, inhibits the dopamine transporter. J. Neurochem. 2011, 118, 714-720. [CrossRef]

44. Fritts, M.E.; Mueller, K.; Morris, L. Amphetamine-Induced Locomotor Stereotypy in Rats Is Reduced by a D1 but not a D2 Antagonist. Pharmacol. Biochem. Behav. 1997, 58, 1015-1019. [CrossRef]

45. Althobaiti, Y.; Alghorabi, A.; AlShehri, F.S.; Baothman, B.; Almalki, A.H.; Alsaab, H.; Alsanie, W.; Gaber, A.; Almalki, H.; Alghamdi, A.S.; et al. Gabapentin-induced drug-seeking-like behavior: A potential role for the dopaminergic system. Sci. Rep. 2020, 10, 1-8. [CrossRef] [PubMed]

46. Althobaiti, Y.; Almalki, A.; Alsaab, H.; Alsanie, W.; Gaber, A.; Alhadidi, Q.; Hardy, A.M.G.; Nasr, A.; Alzahrani, O.; Stary, C.M.; et al. Pregabalin: Potential for Addiction and a Possible Glutamatergic Mechanism. Sci. Rep. 2019, 9, 1-8. [CrossRef] [PubMed]

47. Althobaiti, Y.S. Role of venlafaxine in relapse to methamphetamine seeking: Potential treatment option for drug dependence. Saudi Med. J. 2019, 40, 339. [CrossRef] [PubMed] 